\title{
Epiphytic microlichens as indicators of phytosociological differentiation between Caatinga and Brejos de Altitude
}

\author{
Amanda Barreto Xavier Leite ${ }^{1 *}$, Aline Anjos de Menezes ${ }^{1}$, Leandro de Sousa Souto ${ }^{1}$, André Aptroot ${ }^{2}$, \\ Robert Lücking ${ }^{3}$, Viviane Monique dos Santos ${ }^{4}$ and Marcela Eugenia da Silva Cáceres ${ }^{1,4}$
}

Received: February 2, 2015 Accepted: June 1, 2015

\begin{abstract}
The present study tested the hypothesis that species richness and composition of epiphytic microlichens can be used to support the phytosociological differentiation between Caatinga and Brejos de Altitude, as exemplified by the Muralha Reserve (Caatinga) and the Parque Estadual Mata do Pau Ferro (Brejo de Altitude), in the state of Paraíba, Brazil. A total of 755 lichen samples were collected, comprising 18 families, 42 genera and 111 species of epiphytic, corticolous microlichens. Overall species richness was higher in the Caatinga, with 67 species, compared to the Brejo, with 46 species. Species richness per sample was significantly higher in the Caatinga compared to the Brejo. Taxonomic composition also differed significantly between the two areas, with Arthoniaceae, Caliciaceae, Chrysothrichaceae, Graphidaceae (particularly Graphis), Lecanoraceae, Mycoporaceae, Pertusariaceae, and Trypetheliaceae being dominant in, or exclusive to, the Caatinga, whereas Coenogoniaceae, Graphidaceae (Diorygma, Fissurina, Myriotrema, Ocellularia, Phaeographis, Sarcographa), Malmideaceae, Porinaceae and Strigulaceae were dominant in, or exclusive to, the Brejo. Five new species were discovered as result of this study. This is the first study to quantitatively compare richness and community patterns of epiphytic microlichens between two major biomes in Northeastern Brazil, and the first detailed lichen study in the state of Paraíba.
\end{abstract}

Keywords: corticolous microlichens, Mata Pau-Ferro, Reserva Muralha, species composition, species richness

\section{Introduction}

Lichens are symbiotic associations between a fungus and one or more species of algae or cyanobacteria (Nash III 2008). Among the fungi involved in this association, circa $99 \%$ are members of the Ascomycota, while the remaining species belong to the Basidiomycota (Webster \& Weber 2007). Lichenization is a successful evolutionary strategy that has resulted in a rich diversity of fungal species (Grube \& Kroken 2000). Due to peculiar morphological and ecophysiological characteristics which are a result of the symbiotic relation, lichenized fungi are found almost in all terrestrial ecosystems (Umaña \& Sipman 2002; Lakatos et al 2006), in nearly all habitats from the tropics to the Polar Regions (Nash III 2008), in environments where they would be unable to live if non-lichenized (Chaparro \& Ceballos 2002).

Lichenized fungi constitute a significant portion of forest biodiversity worldwide (DeBolt et al. 2007; Feuerer \& Hawksworth 2007; Lücking et al. 2009), but accurate knowl- edge of lichen diversity is limited, especially in the tropics (Cáceres 2007). Lichens can be saxicolous, i.e. growing on rocks, terricolous, i.e. on soil, muscicolous or hepaticolous on bryophytes, foliicolous on the surface of living leaves, and corticolous on the bark of trees, which is the majority of epiphytic species. Substrate features and abiotic factors have been shown to influence the distribution and occurrence of lichen species (Purvis 2000; Aptroot \& Herk 2007; Dyer \& Letourneau 2007; Käffer et al. 2007; 2010; 2015; Bunnell et al. 2008; Mezaka et al. 2008; Morales et al. 2009).

Ecological studies on lichens in northeastern Brazil have been undertaken, first with foliicolous (Cáceres et al. 2000), and then corticolous microlichens (Cáceres et al. 2007; 2008a; b; Cavalcante 2012; Rodrigues 2012). These works focused mostly on the comparison between different vegetation types at the landscape scale but also analyzed biotic and abiotic features in relation to lichen species richness and composition within a given habitat.

The so-called Brejos de Altitude are Atlantic Forest enclaves in the semiarid region of northeastern Brazil, sur-

\footnotetext{
${ }^{1}$ Programa de Pós-graduação em Ecologia e Conservação, Universidade Federal de Sergipe, 49100-000, São Cristóvão, Sergipe, Brazil

${ }^{2}$ ABL Herbarium, G.v.d.Veenstraat 107, NL-3762 XK Soest, The Netherlands

${ }^{3}$ Department of Botany, The Field Museum, 1400 South Lake Shore Drive, Chicago, Illinois 60605-2496, USA

${ }^{4}$ Laboratório de Liquenologia, Departamento de Biociências, Universidade Federal de Sergipe, 49500-000, Itabaiana, Sergipe, Brazil

"Corresponding author: amandabxleite@hotmail.com
} 
rounded by Caatinga areas, which represent a much drier, seasonal vegetation. Brejos de Altitude are thus islands of montane forest, with altitudes ranging from 600 to $1000 \mathrm{~m}$ (Andrade-Lima 1966; Andrade et al. 2006). The Brazilian Northeast Region comprises approximately 40 areas of Brejos de Altitude, distributed in the states of Ceará, Rio Grande do Norte, Paraíba and Pernambuco (Tabarelli \& Santos 2004).

The Caatinga is a seasonally dry forest that covers most of the states of Piauí, Ceará, Rio Grande do Norte, Paraíba, Pernambuco, Alagoas, Sergipe, Bahia and the northeastern part of Minas Gerais in the Jequitinhonha Valley (Leal et al. 2005). Caatinga is a xerophytic vegetation characterized by spiny wooden plants succulents, which are able to resist long periods of drought. The Caatinga lies in a semiarid region; its vegetation lacks the green lushness of tropical rainforests (Leal et al. 2005), but it is possible to find high rates of endemism since many species are highly adapted to this biome (Abilio et al. 2010).

While Caatinga and Brejos are geographically close and adjacent, their floristic composition is quite different, owing to the different ecological conditions. This has also been shown for lichens at the landscape scale (Cáceres et al. 2008), but never been tested using quantitative sampling. The present work thus aimed to analyze the diversity of corticolous lichens in two vegetation types, Caatinga and Brejo de Altitude, in the state of Paraíba, comparing species richness and composition and testing the hypothesis that, using these two variables, lichens can be used as indicators of phytosociological differences between the two biomes.

\section{Material and methods}

Lichen specimens were sampled in July 2012 in two areas of Brejo de Altitude and Caatinga in the state of Paraíba, Brazil. The Brejo de Altitude was represented the Mata do Pau Ferro State Park ( $06^{\circ} 58^{\prime} \mathrm{S}$ and $\left.35^{\circ} 42^{\prime} \mathrm{W}\right)$, with an area of circa 600 ha and an altitude between 400 and $600 \mathrm{~m}$, located $5 \mathrm{~km}$ West of the municipality of Areia (Barbosa et al. 2005; Andrade et al. 2006). The vegetation of this park presents itself as a mosaic formed by forest fragments in various stages of ecological succession (Oliveira et al. 2006). The Caatinga area was located in the Muralha Reserve (06 $36^{\prime} \mathrm{S}$ and $36^{\circ} 12^{\prime} \mathrm{W}$ ), with a total of 300 ha and an altitude of circa $500 \mathrm{~m}$, located in the municipality of Cuité.

The sampling method was adapted from Cáceres et al. (2007), according to which five $100 \mathrm{~m}$ long parallel transects were delimited in each locality, and each transect was placed $25 \mathrm{~m}$ apart from one another. Along each transect a sampling point was marked every $10 \mathrm{~m}$, totaling 50 points for each studied area. At each point, the nearest tree with lichen cover was selected and the lichen thalli were sampled. This way, each tree was considered a sample unit.

Small pieces lichen thalli for determination were removed from the tree trunk using knife and hammer. The samples were immediately stored in paper envelopes, in which the name of the site, date, transect and point number were recorded. Identification and descriptive work was carried out in Itabaiana, Universidade Federal de Sergipe, using a Leica EZ4 stereomicroscope and a Leica DM500 compound microscope, and also in Soest using an Olympus SZX7 stereomicroscope and an Olympus BX50 compound microscope with interference contrast, connected to a Nikon Coolpix digital camera. Sections have been mounted in tapwater, in which all measurements were taken, and also the reaction of ascospores to IKI (Lugol solution) has been observed. The specimens are preserved in the ISE Herbarium (Universidade Federal de Sergipe, university campus Prof. Alberto Carvalho). Chemistry was investigated by spot reactions ( $\mathrm{KOH} \mathrm{10 \% ),} \mathrm{underlong-wave} \mathrm{UV}$ light, and thin-layer chromatography (TLC) using solvent A (Orange et al. 2001).

Generalized linear models (GLM's; Gotelli \& Ellison 2011) were used to compare the species richness between both areas. Analyses were performed using the software R (R Development CoreTeam 2008 Version 2.14.2). Minimal models were obtained by removal of non-significant variables ( $\mathrm{p}>0.05$ ) (Crawley 2007).

To study the species composition between areas and samples, the degree of similarity was measured with the Sørensen Similarity Index (Sørensen 1948), which states: $\mathrm{S}=2 \mathrm{X} \mathrm{n}_{\text {comum }} /\left(\mathrm{n}_{\mathrm{a}+\mathrm{nb}}\right)$, where $\mathrm{S}=$ similarity index; $\mathrm{n}_{\text {comum }}=$ number of species in common between the two studied localities, "a" (Brejo de Altitude) and "b" (Caatinga) (or

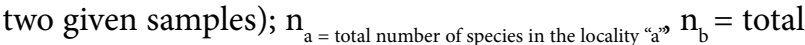
number of species in locality " $b$ ". Thus, the index ranges from 0 (maximum difference) and 1 (maximum similarity).

Furthermore, sample similarity with regard to vegetation type was analyzed using clustering (Cáceres et al. 2008a), with Sørensen as distance measure, using PC-ORD 5.33 (McCune \& Mefford 2006).

\section{Results}

A total of 755 specimens were sampled in the two study areas, representing 18 families, 42 genera and 111 species (Tab. 1). Of these, 13 species were new records for the Northeast region, 14 were recorded for the first time to Brazil and five new records for South America (Fig. 1). All 111 species reported here are also new records for Paraíba, due to lack of previous lichen studies in this state.

Five species were discovered as new to science and are described elsewhere: Coenogonium chloroticum (XavierLeite et al. 2014a); Polymeridium isohypocrellinum (Aptroot et al. 2013a); Stirtonia microspora, S. nitida, and S. nivea (Xavier-Leite et al. 2014b).

Species richness per locality differed for the two areas, with the higher number of species found in the Muralha Reserve (Caatinga), with a total of 67, and 46 species reported for the Parque Estadual Mata do Pau Ferro, the Brejo de 
Table 1. Species of epiphytic microlichens found in Caatinga and Brejo de Altitude in the state of Paraíba, indicating new records for Northeast Brazil, Brazil, and South America.

\begin{tabular}{|c|c|c|c|c|}
\hline Family & Species & Brejo de Altitude & Caatinga & New occurence \\
\hline \multirow[t]{6}{*}{ Arthoniaceae } & Arthonia antillarum (Fée) Nyl. & & $\mathrm{x}$ & Northeast Brazil \\
\hline & Arthonia complanata Fée & & $\mathrm{x}$ & Paraíba \\
\hline & Arthonia parantillarum Aptroot & & $\mathrm{x}$ & Brazil \\
\hline & Stirtonia microspora Xavier-Leite, M. Cáceres \& Aptroot & & $\mathrm{x}$ & New species \\
\hline & Stirtonia nitida Xavier-Leite, M. Cáceres \& Aptroot & & $\mathrm{x}$ & New species \\
\hline & Stirtonia nivea Xavier-Leite, M. Cáceres \& Aptroot & & $\mathrm{x}$ & New species \\
\hline \multirow[t]{9}{*}{ Caliciaceae } & Amandinea extenuata Müll. Arg. & & $\mathrm{x}$ & Paraíba \\
\hline & Buellia yaucoensis Vainio & & $\mathrm{x}$ & Brazil \\
\hline & Cratiria obscurior (Stirton) Marbach \& Kalb & & $\mathrm{x}$ & Paraíba \\
\hline & Dirinaria confluens (Fr.) D. D. Awashti & & $\mathrm{x}$ & Paraíba \\
\hline & Dirinaria leopoldii (Stein) D. D. Awasthi & & $\mathrm{x}$ & Paraíba \\
\hline & Hafellia bahiana Malme & & $\mathrm{x}$ & Paraíba \\
\hline & Hafellia desertica Marbach & & $\mathrm{x}$ & Paraíba \\
\hline & Hafellia dissa (Stirt.) H. Mayrhofer \& Sheard & & $\mathrm{x}$ & Nordeste \\
\hline & Pyxine berteriana (Fée) Imsh. & & $\mathrm{x}$ & Paraíba \\
\hline Chrysothrichaceae & Chrysothrix xanthina (Vain.) Kalb & & $\mathrm{x}$ & Paraíba \\
\hline \multirow[t]{6}{*}{ Coenogoniaceae } & Coenogonium chloroticum Xavier-Leite, M. Cáceres \& Aptroot & $\mathrm{x}$ & & New species \\
\hline & Coenogonium luteocitrinum Rivas Plata, Lücking \& Umaña & $\mathrm{x}$ & & Paraíba \\
\hline & Coenogonium nepalense (G. Thor \&Vezda) Lücking, Aptroot \& Sipman & $\mathrm{x}$ & & Northeast Brazil \\
\hline & Coenogonium saepincola Aptroot, Sipman \& Lücking & $\mathrm{x}$ & & South America \\
\hline & Coenogonium siquirrense f. denticulatum Rivas Plata \&Lücking & $\mathrm{x}$ & & Northeast Brazil \\
\hline & Coenogonium subfallaciosum (Vězda \& Farkas) Lücking, Aptroot \& Sipman & $\mathrm{x}$ & & Brazil \\
\hline Eremithallaceae & Eremithallus marusae R. Miranda, Gaya \& Lücking & $\mathrm{x}$ & & South America \\
\hline \multirow[t]{21}{*}{ Graphidaceae } & Chapsa discoides (Stirt.) Lücking & & $\mathrm{x}$ & Northeast Brazil \\
\hline & Diorygma poitaei (Fée) Kalb, Staiger \& Elix & $\mathrm{x}$ & & Paraíba \\
\hline & Fissurina aggregatula Common \& Lücking & $\mathrm{x}$ & & South America \\
\hline & Fissurina incrustans Fée & $\mathrm{x}$ & & Paraíba \\
\hline & Fissurina pseudostromatica Lücking \& Rivas Plata & $\mathrm{x}$ & & South America \\
\hline & Glyphis scyphulifera (Ach.) Staiger & & $\mathrm{x}$ & Paraíba \\
\hline & Graphis albissima Müll. Arg. & & $\mathrm{x}$ & Brazil \\
\hline & Graphis arbusculaeformis (Vain.) Lücking & & $\mathrm{x}$ & Paraíba \\
\hline & Graphis cincta (Pers.) Aptroot & & $\mathrm{x}$ & Brazil \\
\hline & Graphis conferta Zenker & & $\mathrm{x}$ & Paraíba \\
\hline & Graphis furcata Fée & & $\mathrm{x}$ & Paraíba \\
\hline & Graphis glaucescens Fée & $\mathrm{x}$ & & Paraíba \\
\hline & Graphis gonimica Zahlbr. & & $\mathrm{x}$ & Brazil \\
\hline & Graphis handelii Zahlbr. & & $\mathrm{x}$ & Paraíba \\
\hline & Graphis kelungana Zahlbr. & & $\mathrm{x}$ & Brasil \\
\hline & Graphis leptocarpa Fée & $\mathrm{x}$ & $\mathrm{x}$ & Paraíba \\
\hline & Graphis marginata Raddi & & $\mathrm{x}$ & Paraiba \\
\hline & Graphis lineola Ach. & & $\mathrm{x}$ & Paraíba \\
\hline & Graphis oxyclada Müll. Arg. & & $\mathrm{x}$ & Paraíba \\
\hline & Graphis pavoniana Fée & & $\mathrm{x}$ & Paraíba \\
\hline & Graphis pinicola Zahlbr. & $\mathrm{x}$ & $\mathrm{x}$ & Paraíba \\
\hline
\end{tabular}


Tabela 1. Continuation.

\begin{tabular}{|c|c|c|c|c|}
\hline Family & Species & Brejo de Altitude & Caatinga & New occurence \\
\hline & Graphis submarginata Lücking & & $\mathrm{x}$ & Paraíba \\
\hline & Leucodecton expallescens (Nyl.) Rivas Plata \& Lücking & & $\mathrm{x}$ & Brazil \\
\hline & Leucodecton occultum (Eschw.) Frisch & & $\mathrm{x}$ & Brazil \\
\hline & Myriotrema clandestinoides Sipman \&Lücking & $\mathrm{x}$ & & Northeast Brazil \\
\hline & Ocellularia obturascens (Nyl.) Hal & $\mathrm{x}$ & & Brazil \\
\hline & Phaeographis brasiliensis (A. Massal.) Kalb \& Matthes-Leicht & $\mathrm{x}$ & & Paraíba \\
\hline & Phaeographis neotricosa Redinger & $\mathrm{x}$ & & Paraíba \\
\hline & Sarcographa labyrinthica (Ach.) Müll. Arg. & $\mathrm{x}$ & & Paraíba \\
\hline \multirow[t]{2}{*}{ Gyalectaceae } & Ramonia intermedia Kalb & $\mathrm{x}$ & & Paraíba \\
\hline & Ramonia microspora Vězda & $\mathrm{x}$ & & Northeast Brazil \\
\hline \multirow[t]{5}{*}{ Lecanoraceae } & Haematomma persoonii (Fée) A. Massal. & & $\mathrm{x}$ & Paraíba \\
\hline & Lecanora achroa Nyl. & & $\mathrm{x}$ & Paraíba \\
\hline & Lecanora helva Stizenb. & & $\mathrm{x}$ & Paraíba \\
\hline & Lecanora tropica Zahlbr. & & $\mathrm{x}$ & Paraíba \\
\hline & Ramboldia haematites (Fée) Kalb & & $\mathrm{x}$ & Paraíba \\
\hline \multirow[t]{9}{*}{ Malmideaceae } & Malmidea aff. granifera (Ach.) Kalb, Rivas Plata \& Lumbsch & $\mathrm{x}$ & & Paraíba \\
\hline & Malmidea aff. piperis (Spreng.) Kalb, Rivas Plata \& Lumbsch & $\mathrm{x}$ & & Paraíba \\
\hline & Malmidea atlantica Cáceres \& Kalb & $\mathrm{x}$ & & Paraíba \\
\hline & Malmidea furfurosa (Tuck. ex Nyl.) Kalb \& Lücking & $\mathrm{x}$ & & Paraíba \\
\hline & Malmidea granifera (Ach.) Kalb, Rivas Plata \& Lumbsch & $\mathrm{x}$ & & Paraíba \\
\hline & Malmidea gyalectoides (Vain.) Kalb \& Lücking & $\mathrm{x}$ & & Paraíba \\
\hline & Malmidea leptoloma (Müll. Arg.) Kalb \& Lücking & $\mathrm{x}$ & & Paraíba \\
\hline & Malmidea piperis (Spreng.) Kalb, Rivas Plata \& Lumbsch & $\mathrm{x}$ & & Paraíba \\
\hline & Malmidea vinosa (Eschw.) Kalb, Rivas Plata \& Lumbsch & $\mathrm{x}$ & & Paraíba \\
\hline \multirow[t]{2}{*}{ Monoblastiaceae } & Anisomeridium albisedum (Nyl.) R.C. Harris & $\mathrm{x}$ & & Brazil \\
\hline & Anisomeridium tamarindi (Fée) R. C. Harris & & $\mathrm{x}$ & Paraíba \\
\hline Mycoporaceae & Mycoporum eschweileri (Müll. Arg.) R.C. Harris & & $\mathrm{x}$ & Brasil \\
\hline \multirow[t]{3}{*}{ Pertusariaceae } & Pertusaria dehiscens Müll. Arg. & & $\mathrm{x}$ & Paraíba \\
\hline & Pertusaria flavens Nyl. & & $\mathrm{x}$ & Paraíba \\
\hline & Pertusaria quassiae (Fée) Nyl. & & $\mathrm{x}$ & Paraíba \\
\hline \multirow[t]{6}{*}{ Porinaceae } & Porina conspersa Malme & $\mathrm{x}$ & & Paraíba \\
\hline & Porina curtula Malme & $\mathrm{x}$ & & Paraíba \\
\hline & Porina imitatrix Müll. Arg. & $\mathrm{x}$ & & Paraíba \\
\hline & Porina nucula Ach. & $\mathrm{x}$ & & Paraíba \\
\hline & Porina subepiphylla Lücking \& Vězda & $\mathrm{x}$ & & Paraíba \\
\hline & Porina subpungens Malme & $\mathrm{x}$ & & Northeast Brazil \\
\hline \multirow[t]{6}{*}{ Pyrenulaceae } & Pyrenula anomala (Ach.) Vain. & & $\mathrm{x}$ & Paraíba \\
\hline & Pyrneula aspistea (Ach.) Ach. & & $\mathrm{x}$ & Northeast Brazil \\
\hline & Pyrenula brunnea Fée & $\mathrm{x}$ & & Northeast Brazil \\
\hline & Pyrenula infraleucotrypa Aptroot \& M. Cáceres & $\mathrm{x}$ & & Paraíba \\
\hline & Pyrenula inframamillana Aptroot \& M. Cáceres & $\mathrm{x}$ & & Northeast Brazil \\
\hline & Pyrenula quassiaecola Fée & & $\mathrm{x}$ & Paraíba \\
\hline
\end{tabular}




\begin{tabular}{|c|c|c|c|c|}
\hline Family & Species & Brejo de Altitude & Caatinga & New occurence \\
\hline & Pyrenula septicollaris (Eschw.) R. C. Harris & $\mathrm{x}$ & & Paraíba \\
\hline & Pyrenula subglabrata (Nyl.) Müll. Arg. & & $\mathrm{x}$ & Brazil \\
\hline Ramalinaceae & Bacidia cuyabensis Malme & & $\mathrm{x}$ & Northeast Brazil \\
\hline \multirow[t]{10}{*}{ Roccellaceae } & Chiodecton malmei G. Thor & & $\mathrm{x}$ & Paraíba \\
\hline & Enterographa compunctula (Nyl.) Redinger & & $\mathrm{x}$ & Paraíba \\
\hline & Enterographa sipmanii Sparrius & & $\mathrm{x}$ & Paraíba \\
\hline & Enterographa subserialis (Nyl.) Redinger & & $\mathrm{x}$ & South America \\
\hline & Mazosia ocellata (Nyl.) R. C. Harris & $\mathrm{x}$ & & Paraíba \\
\hline & Opegrapha aperiens Vain & $\mathrm{x}$ & & Northeast Brazil \\
\hline & Opegrapha aff. contracta Vain. & $\mathrm{x}$ & & Paraíba \\
\hline & Opegrapha cylindrica Raddi & $\mathrm{x}$ & & Paraíba \\
\hline & Opegrapha robusta Raddi & & $\mathrm{x}$ & Paraíba \\
\hline & Sclerophyton elegans Eschw. & & $\mathrm{x}$ & Paraíba \\
\hline Strigulaceae & Strigula phaea (Ach.) R. C. Harris & $\mathrm{x}$ & & Brazil \\
\hline \multirow[t]{11}{*}{ Trypetheliaceae } & Arthopyrenia cinchonae (Ach.) Müll. Arg. & & $\mathrm{x}$ & Paraíba \\
\hline & Mycomicrothelia oleosa Aptroot & & $\mathrm{x}$ & Northeast Brazil \\
\hline & Polymeridium multiforme Aptroot & & $\mathrm{x}$ & Paraiba \\
\hline & Polymeridium proponens (Nyl.) R. C. Harris & & $\mathrm{x}$ & Paraíba \\
\hline & Polymeridium quinqueseptatum (Nyl.) R. C. Harris & & $\mathrm{x}$ & Paraíba \\
\hline & Polymeridium isohypocrellinum A. B. Xavier-Leite, M. Cáceres \& Aptroot & & $\mathrm{x}$ & New species \\
\hline & Trypethelium aeneum (Eschw.) Zahlbr. & & $\mathrm{x}$ & Paraíba \\
\hline & Trypethelium eluteriae Spreng. & & $\mathrm{x}$ & Paraíba \\
\hline & Trypethelium ochroleucum (Eschw.) Nyl. & & $\mathrm{x}$ & Paraíba \\
\hline & Trypethelium subeluteriae Makhija \& Patw. & & $\mathrm{x}$ & Paraíba \\
\hline & Trypethelium tropicum (Ach.) Müll. Arg. & & $\mathrm{x}$ & Paraíba \\
\hline
\end{tabular}

Altitude area (Fig. 2). Species richness at sample scale was significantly higher for the Caatinga area $(\mathrm{p}<0.05)$. Among the species recorded for the Caatinga, 65 (97\%) occurred exclusively in this biome and 44 taxa (93\%) were exclusive to the Brejo de Altitude.

The families with highest species richness in the Caatinga were Graphidaceae and Caliciaceae, and Graphis was the most representative genus. For the Brejo de Altitude, the most diverse families were Graphidaceae and Malmideaceae, and the genus Malmidea had the higher number of species. While Graphidaceae were dominant in both vegetation types, different genera and species of the family were characteristic for each type.

Coenogoniaceae, Eremithallaceae, Gyalectaceae, Malmideaceae, Porinaceae and Strigulaceae were families found only at the Mata do Pau Ferro State Park, together with the genera Coenogonium, Eremithallus, Diorygma, Fissurina, Myriotrema, Ocellularia, Phaeographis, Sarcographa, Ramonia, Malmidea, Porina, Mazosia and Strigula, which were not present in the Caatinga.
On the other hand, restricted to the Caatinga were the families Arthoniaceae, Caliciaceae, Chrysothrichaceae, Lecanoraceae, Mycoporaceae, Pertusariaceae, Ramalinaceae and Trypetheliaceae. The genera Arthonia, Arthothelium, Stirtonia, Arthopyrenia, Mycomicrothelia, Amandinea, Chrysothrix, Chapsa, Leucodecton, Haematomma, Lecanora, Ramboldia, Mycoporum, Pertusaria, Buellia, Cratiria, Dirinaria, Hafellia, Pyxine, Physcia, Hyperphyscia, Bacidia, Chiodecton, Dirina, Enterographa, Sclerophyton, Polymeridium, and Trypethelium were only found in the Caatinga.

The families Graphidaceae, Monoblastiaceae, Pyrenulaceae, and Roccellaceae, and the genera Anisomeridium, Glyphis, Graphis, Opegrapha, and Pyrenula, plus the three species, Glyphis scyphulifera, Graphis leptocarpa and Graphis pinicola, were found both in Brejo de Altitude and in the Caatinga. Consequently, the Sørensen similarity index between the two areas amounts to only $4 \%$. The clear phytosociological distinction in species composition of epiphytic microlichens between the two areas was also evident in the cluster analysis, with the formation of two distinct clusters representing Caatinga and Brejo de Altitude (Fig. 3). 

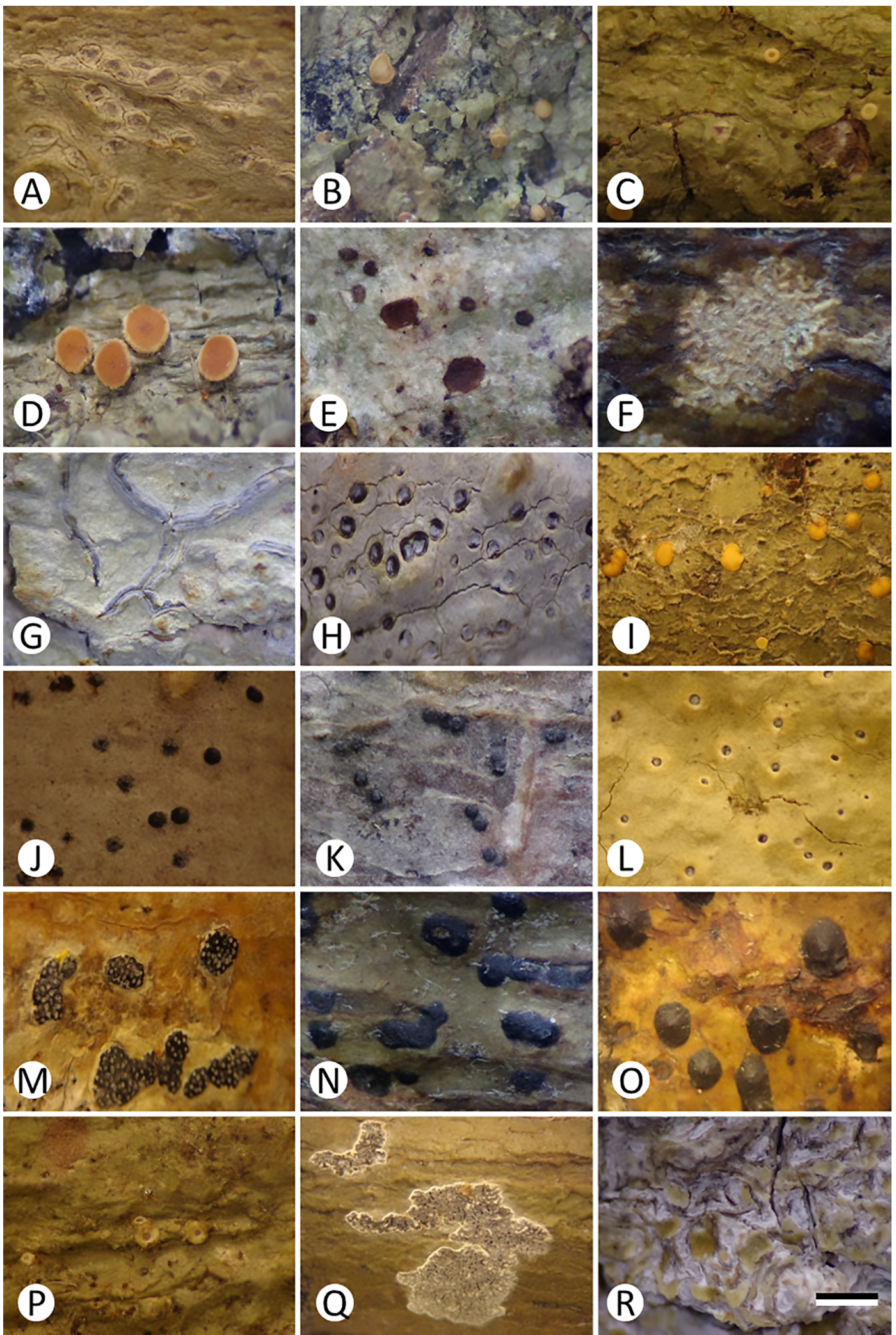

Figure 1. Selected epiphytic microlichens from this study. (A) Chapsa discoides (Stirt.) Lücking; (B) Coenogonium chloroticum A. B. Xavier-Leite, M. Cáceres \&Aptroot; (C) Coenogonium nepalense (G. Thor \& Vezda) Lücking, Aptroot \& Sipman; (D) Coenogonium siquirrense f. denticulatum Rivas Plata \& Lücking; (E) Eremithallus marusae R. Miranda, Gaya \& Lücking; (F) Fissurina pseudostromatica Lücking \& Rivas-Plata; (G) Graphis glaucescens Fée; (H) Leucodecton occultum (Eschw.) Frisch; (I) Malmidea gyalectoides (Vain.) Kalb \& Lücking; (J) Mycomicrothelia oleosa Aptroot; (K) Mycoporum eschweileri (Müll. Arg.) R.C. Harris; (L) Ocellularia obturascens (Nyl.) Hale; (M) Pyrenula anômala (Ach.) Vain.; (N) Pyrenula infraleucotrypa Aptroot \& M. Cáceres; (O) Pyrenula inframamillana Aptroot \& M. Cáceres; (P) Ramonia microspora Vězda; (Q) Sarcographa labyrinthica (Ach.) Müll. Arg.; (R) Stirtonia nivea A. B. Xavier-Leite, M. Cáceres \& Aptroot. Scale bars: 0.5 mm. 


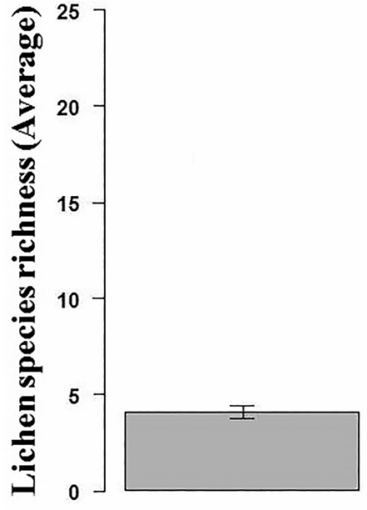

BA

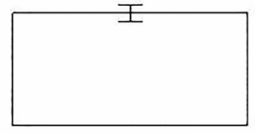

CA

Figure 2. Means species richness $( \pm \mathrm{SE})$ per sample of epiphytic microlichens for the areas of Brejo de Altitude $(\mathrm{BA})$ and Caatinga $(\mathrm{CA})$. ( $\mathrm{p}<0.05)$

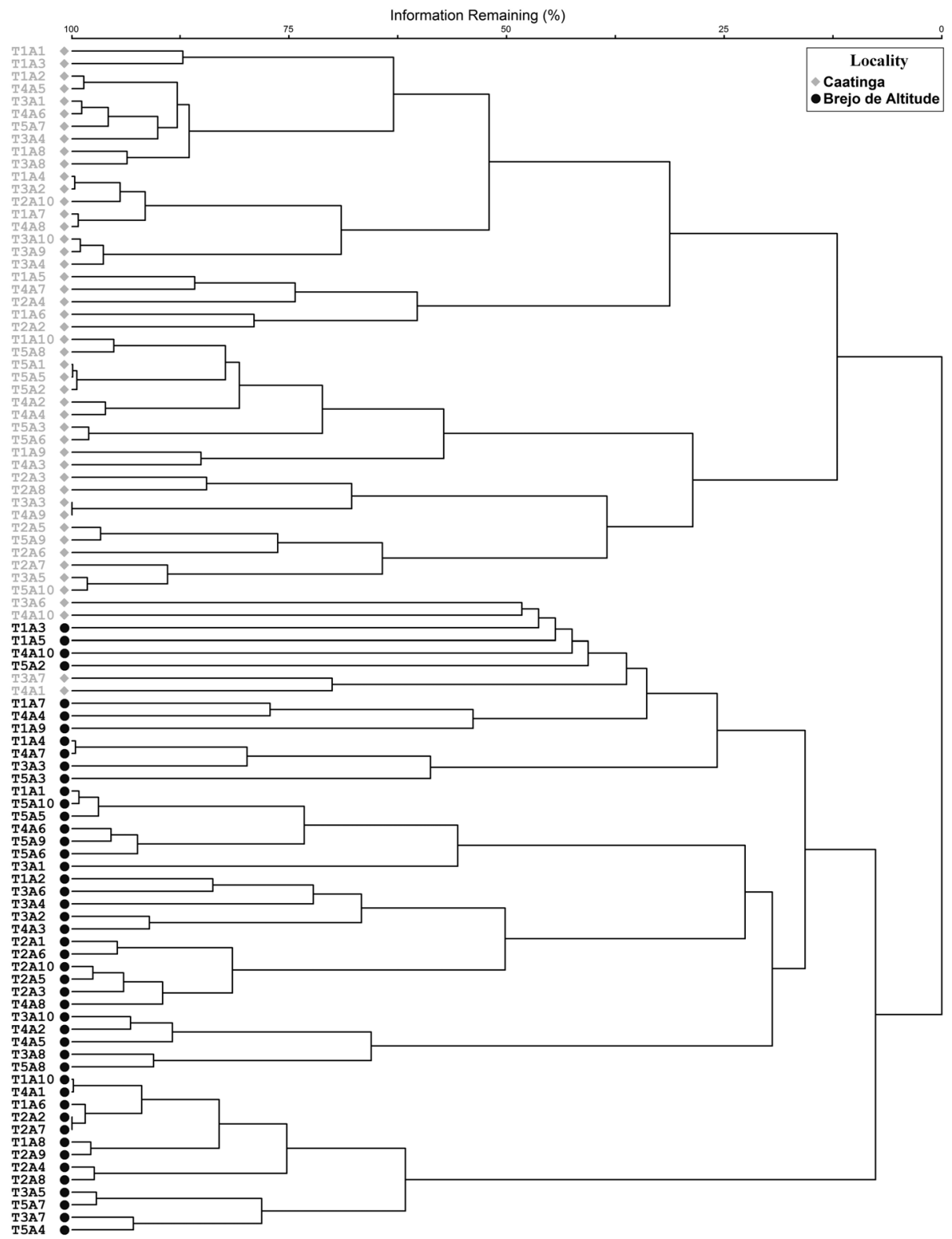

Figure 3. Cluster dendrogram of the studied samples and their grouping based on lichen species composition, correlating strongly with vegetation type. 


\section{Discussion}

No lichen study has previously been carried out in the Parque Estadual Mata do Pau-Ferro. The only inventories undertaken in this park concerned the species diversity and floristic composition of bryophytes (Pôrto et al. 2004; 2005) and phanerogams (Andrade et al. 2006; Oliveira et al. 2006). In the Reserva Muralha, there was only one study on the diversity of phanerogams (Barbosa et al. 2005). The only previous investigations concerning lichens in Paraíba dealt with species of Cladoniaceae (Ahti et al. 1993) and the lichen Cladonia verticillaris (Villarouco et al. 2007). Thus, this is the first comprehensive work on lichen diversity, focusing on epiphytic microlichens, in the state of Paraíba.

The comparison of species richness between the two areas showed a higher value for the Caatinga compared to the Brejo de Altitute, in contrast to what was found by Cáceres et al. (2008a), where the Brejos de Altitude were more diverse. The different results found here may be due to the disparity in sampling technique, since opportunistic sampling had been used in the previous work. Cáceres et al. (2008b) showed that the sampling method is critical for estimating species richness of lichens within a given area, indicating that the transects (quantitative method) used in the present study is most efficient for microlichen inventories. On the other hand, since the same technique was used for both regions, this might not actually explain the differences. Another reason could be that the Caatinga sites studied by Cáceres et al. (2008a) were less well conserved than the site studied here and hence had lower lichen species richness. A further possible explanation for the lower species richness found here in the Brejo de Altitude would be increased competition with organisms such as bryophytes due to the climatic conditions. According to Pôrto et al. (2005), epiphytic bryophyte biomass in the Brejo de Altitude areas of Paraíba State is rather high, and this competition can result in a change in community structure along the tree trunk in favor of bryophytes (Martins \& Marcelli 2011).

The low similarity in species composition, with a value of only $4 \%$ between the two areas, corroborates the findings by Cáceres et al. (2008a), where the differences in species composition between the Caatinga and Brejo de Altitude were similarly high. Yet, high occurrence of Graphidaceae for these two areas and Malmideaceae for the Brejo de Altitude, with the most common genus being Graphis for Caatinga and Malmidea for Brejo de Altitude, is in accordance with what was previously found by Cáceres (2007). This confirms that Graphidaceae is an important component of tropical lichenized mycota and generally abundant in both vegetation types, and that Malmideaceae is more typical of humid forests such as the more closed rainforests of the Brejo de Altitude.

Most of the taxa recorded here for the Caatinga area were also shown to be present in this vegetation type in other states in previous studies. Anisomeridium tamarindi, Chrysothrix xanthina, Enterographa sipmanii and Graphis oxyclada had been already cited by Cáceres (2007) for Pernambuco. There are also previous records for Graphis arbusculaeformis, $G$. handelii, Hafellia bahiana, $H$. curatellae, and $H$. desertica for Alagoas (Menezes et al. 2011; Cavalcante 2012). For the semiarid region in Sergipe and Alagoas, Graphis lineola had also been reported (Cavalcante 2012; Rodrigues 2012). Dirinaria confluens, Lecanora helva, and Pyxine berteriana were previously registered for Pernambuco and Alagoas (Cáceres 2007; Menezes et al. 2011; Cavalcante 2012). Cratiria obscurior, Dirinaria leopoldii, Graphis submarginata, Haematomma personii, Pertusaria dehiscens, P. flavens, and Ramboldia haematites were previously mentioned for the states of Alagoas, Pernambuco and Sergipe (Cáceres 2007; Menezes et al. 2011; Cavalcante 2012; Rodrigues 2012).

The species found here in the Brejo de Altitude were similar to those previously cited for other Northeastern montane and Atlantic forests, since the vegetation type is similar, with a strong resemblance to the coastal rainforest (Andrade et al. 2006), such as the species Fissurina incrustans, Porina curtula, and P. conspersa, found already in Alagoas (Cáceres 2007). Coenogonium luteocitrinum, Diorygma poitaei, Graphis glaucescens, Malmidea atlantica, M. furfurosa, M. granifera, M. gyalectoides, M. pipers, Mazosia ocellata, Opegrapha cylindrica, Phaeographis neotricosa, Ramonia intermedia, and Sarcographa labyrinthica had all been previously reported for the states of Alagoas, Sergipe, Pernambuco and Rio Grande do Norte (Cáceres 2007).

Among the species common to both areas, only Glyphis scyphulifera was previously cited for Caatinga and Atlantic Forest in northeastern Brazil (Cáceres 2007), and Graphis leptocarpa and G. pinicola were reported from the Caatinga by Menezes et al. (2011) and Rodrigues (2012). Since Brejos de Altitude are considered Atlantic Forest enclaves forming islands of rainforest in the middle of the semiarid region (Andrade-Lima 1966), the emergence of species common to Caatinga in areas of Brejo de Altitude should occur because these montane forests are being degraded and disturbed, with the vegetation becoming more open in some places (Cáceres et al. 2007).

This distinction between composition species of corticolous lichens between these two areas was evident in the cluster analysis, with the formation of two clusters in the points represented by the area of Caatinga and the Brejo de Altitude (Fig. 3).

Regarding new records of corticolous lichens for the Northeast region, the species Amandinea extenuata, Hafellia dissa, Opegrapa aperiens and Pyrenula brunnea were cited before for the Rio Grande do Sul (Spielmann 2006). Pyrenula inframamillana was cited by Aptroot et al. (2013b) for the state of Rondônia.

Regarding new records for Brazil, the species Anisomeridium albisedum, Pyrenula aspistea and Strigula phaea were previously referenced by Aptroot et al. (2008) for Costa Rica, as well as Chapsa discoides, Myriotrema clandestinoides, Leucodecton expallescens, L. occultum and Ocellularia obturascens for the same country by Sipman et al. (2012). Also with previous 
records for Costa Rica, Rivas-Plata et al. (2006) reported the species Coenogonium nepalense, C. siquirrensef. denticulatum and C. subfallaciosum. Other new records for the country are Arthonia parantillarum cited from Taiwan by Aptroot \& Sparrius (2003), Buellia yaucoensis mentioned by Marbach (2000) for the Caribbean, Ramonia microspora from Argentina by Lücking et al. (2009), and Graphis gonimica referenced from China and Fissurina pseudostromatica from Colombia by Rincón-Espitia (2011). For South America the new record Coenogonium saepincola was cited by Rivas-Plata et al. (2006) for Costa Rica. Eremithallus marusae was previously mentioned by Lumbsch et al. (2011) from Mexico, and Fissurina aggregatula by Lücking et al. (2011) from the United States.

In conclusion, the present work is one of the first studies about lichen diversity in the state of Paraíba and the first to study the lichens of Brejos de Altitude, comparing its composition and richness with that of Caatinga vegetation in the same state. As our results show, such studies can reveal significant, previously unrecognized organismic diversity, in this case 111 new records for the state five new species to science. Such studies are of paramount importance for the understanding of species richness and composition for Brejos de Altitude and Caatinga, as well as serving as a basis and further incentive for studies to be undertaken. The main conclusion, however, is that lichens serve as indicators of phytosociological differences between these major biomes in Northeastern Brazil, as their community composition strongly correlates with vegetation type.

\section{Acknowledgements}

The CNPq (Conselho Nacional de Desenvolvimento Científico e Tecnológico) is thanked for a research grant to MESC (Process 311706/2012-6). PPEC (Programa de Pós-graduacão em Ecologia e Conservação-UFS) for funding the collecting trips. CAPES (Coordenação de Aperfeiçoamento de Pessoal de Nível Superior) provided a Master's Scholarship to ABXL. Data obtained for this study were also gathered as part of several projects funded by the National Science Foundation: Neotropical Epiphytic Microlichens - An Innovative Inventory of a Highly Diverse yet Little Known Group of Symbiotic Organisms (DEB 715660 to The Field Museum; PI R. Lücking), and ATM - Assembling a taxonomic monograph: The lichen family Graphidaceae (DEB-1025861 to The Field Museum; PI T. Lumbsch, CoPI R. Lücking).

\section{References}

Abílio FJP, Florentino HS, Ruffo TLM. 2010. Educação Ambiental no Bioma Caatinga: formação continuada de professores de escolas públicas de São João do Cariri, Paraíba. Pesquisa em Educação Ambiental 5: 171-193.

Ahti T, Stenroos S, Xavier Filho L. 1993. The lichen family Cladoniaceae in Paraiba, Pernambuco and Sergipe, Northeast Brazil. Tropical Bryology 7: 55-70.
Andrade LA, Oliveira, FX, Nascimento IS, Fabricante JR, Sampaio EVSB, Barbosa MRV. 2006. Análise florística e estrutural de matas ciliares ocorrentes em brejo de altitude no município de Areia, Paraíba: Revista Brasileira de Ciências Agrárias 1: 31-40.

Andrade-Lima D. 1966. Esboço fitoecológico de alguns "brejos" de Pernambuco. Boletim Técnico, Instituto de Pesquisas Agronômicas de Pernambuco 8:3-9.

Aptroot A, Sparrius LB. 2003. New microlichens from Taiwan. Fungal Diversity 14: 1-50.

Aptroot A, Herk CM. 2007. Further evidence of the effects of global warming on lichens, particularly those with Trentepholia phycobionts. Environmental Polluiton 146: 293-298.

Aptroot A, Lücking R, Sipman HJM, Umaña L, Chaves JL. 2008. Pyrenocarpous lichens with bitunicate asci: A first assessment of the lichen biodiversity inventory in Costa Rica. Bibliotheca Lichenologica 97: 1-162.

Aptroot A, Menezes AA, Lima EL, Xavier-Leite AB, Cáceres MES. 2013a. New species of Polymeridium from Brazil expand the range of known morphological variation within the genus. The Lichenologist 45: 545-552.

Aptroot A, Sipman HJM, Cáceres MES. 2013b. Twenty-one new species of Pyrenula from South America, with a note on over-mature ascospore. The Lichenologist 45: 169-198.

Barbosa MRV, Lima RB, Agra MF, Cunha JP, Pessoa MCR. 2005. Vegetação e flora fanerogâmica do Curimataú, Paraíba. In: Araújo FS, Rodal MJN, Barbosa MRV. (eds.) Análise das variações da biodiversidade do bioma Caatinga: suporte a estratégias regionais de conservação. Brasília, Ministério do Meio Ambiente. p. 121-128.

Bunnell FL, Spribille T, Houde I, Goward T, Björk C. 2008. Lichens on down wood in logged and unlogged forest stands. Canadian Journal of Forest Research 38: 1033-1041.

Cáceres MES. 2007. Corticolous crustose and microfoliose lichens of northeastern Brazil. Libri Botanici 22: 1-168.

Cáceres MES, Lücking R, Rambold G. 2007. Phorophyte specificity and environmental parameters versus stochasticity as determinants for species composition of corticolous crustose lichen communities in the Atlantic rain forest of northeastern Brazil. Mycological Progress 6: 117-136.

Cáceres MES, Lücking R, Rambold G. 2008a. Corticolous microlichens in Northeastern Brazil: habitat differentiation between coastal Mata Atlântica, Caatinga and Brejos de Altitude. The Bryologist 111: 98-117.

Cáceres MES, Lücking R, Rambold G. 2008b. Efficiency of sampling methods for accurate estimation of species richness of corticolous microlichens in the Atlantic rainforest of northeastern Brazil. Biodiversity and Conservation 17: 1285-1301.

Cáceres MES, Maia LC, Lücking R. 2000. Foliicolous lichens and their lichenicolous fungi in the atlantic rainforest of Brazil: diversity, ecogeography and conservation. Bibliotheca Lichenologica 75: 47-70.

Cavalcante JG. 2012. Fatores associados à estrutura da comunidade de liquens corticícolas crostosos em duas áreas de caatinga no Estado de Alagoas. Msc Thesis, Universidade Federal de Sergipe, Brazil.

Chaparro MV, Ceballos JA. 2002. Hongos liquenizados. 1st. edn. Bogotá, Universidad Nacional de Colombia.

Crawley MJ. 2007. Statistical computing - an introduction to data analysis using s-plus. London, John Wiley \& Sons.

DeBolt AM, Rosentreter R, Martin EP. 2007. Macrolichen diversity in subtropical forests of north-central Florida. The Bryologist 110: 254-265.

Dyer LA, Letourneau DK. 2007. Determinants of lichen diversity in a rain forest understory. Biotropica 39: 525-529.

Feuerer T, Hawksworth DL. 2007. Biodiversity of lichens, including a world-wide analysis of checklist data based on Takhtajan's floristic regions. Biodiversity and Conservation 16: 85-98.

Gotelli NJ, Ellison AM. 2011. Princípios de estatística em ecologia. Porto Alegre, Artmed.

Grube M, Kroken S. 2000. Molecular approaches and the concept of species and species complexes in lichenized fungi. Mycological Research 104: 1284-1294.

Käffer MI, Cáceres MES, Vargas VMF, Martins SMA. 2010. Novas ocorrências de liquens corticícolas crostosos para a região sul do Brasil. Acta Botanica Brasilica 24: 948-951. 
Käffer MI, Ganade G, Marcelli MP. 2007. Interação entre liquens e forófitos em quatro ambientes na FLONA de São Francisco de Paula. Revista Brasileira de Biociências 5: 216-218.

Käffer ML, Koch AM, Aptroot A, Martins SMAM. 2015. New records of corticolous lichens for South America and Brazil. Plant Ecology and Evolution 148: 111-118.

Lakatos M, Rascher U \& Büdel AB. 2006. Functional characteristics of corticolous lichens in the understory of a tropical lowland rain forest. Journal compilation. New Phytologist 172: 679-695.

Leal IR, Silva JMC, Tabarelli M, Lacher Jr T. 2005. Mudando o curso da conservação da biodiversidade na Caatinga no nordeste do Brasil. Megadiversidade 1: 139-146.

Lücking R, Archer AW, Aptroot A. 2009. A world-wide key to the genus Graphis (Ostropales: Graphidaceae). The Lichenologist 45: 1-90.

Lücking R, Seavey FRS, Common SQ. et al. 2011. The lichens of Fakahatchee Strand Preserve State Park, Florida: Proceedings from the 18th Tuckerman Workshop. Bulletin of the Florida Museum of Natural History 49: 127-186.

Lumbsch HT, Altermann S, Ahti T. et al. 2011. One hundred new species of lichenized fungi: a signature of undiscovered global diversity. Phytotaxa 18: 1-127.

Marbach B. 2000. Corticole und lignicoleArten der Flechtengattung Buellia sensu lato in den Subtropen und Tropen. Bibliotheca Lichenologica 74: 1-384.

Martins SMA, Marcelli M. 2011. Specific distribution of lichens on Dodonaeaviscosa L. in the restinga area of Itapuã State Park in Southern Brazil. Hoehnea 38: 397-411.

McCune B, Mefford MJ. 2006. PC-ORD: multivariate analysis of ecological data. Version 5.14. Gleneden Beach, Oregon, MJM Software.

Menezes AA, Leite ABX, Otsuka AY, Jesus LS, Cáceres MES. 2011. Novas ocorrências de liquens corticícolas crostosos e microfoliosos em vegetação de Caatinga no semi-árido de Alagoas. Acta Botanica Brasilica 25: 885-889.

Mezaka A, Brumelis G, Piterãns A. 2008. The distribuition of epiphytic bryophyte and lichen species in relation to phorophyte characters in Latvian natural old-growth broad leaved forests. Folia Crytogamica Estonica 44: 89-99.

Morales AE, Lücking R, Anze R. 2009. Una Introducción al Estudio de los Líquenes de Bolivia. Cochabamba, Universidad Católica Boliviana "San Pablo".

Nash III TH. 2008. Lichen Biology. 2nd. edn. New York, Cambridge University Press.

Oliveira FX, Andrade LA, Félix LP. 2006. Comparações florísticas e estruturais entre comunidades de Floresta Ombrófila Aberta com diferentes idades, no Município de Areia, PB, Brasil. Acta Botanica Brasilica 20: 861-873.

Orange A, James PW, White FJ. 2001. Microchemical Methods for the Identification of Lichens. London, British Lichen Society.

Pôrto KC, Alvarenga LDP, Santos GHF. 2005. Briófitas. In: Pôrto KC, Tabarelli M, Almeida-Cortez J. (eds.) Diversidade biológica e con- servação da Floresta Atlântica ao norte do rio São Francisco. Recife, Universitária. p. 123-146.

Pôrto KC, Germano SR, Borges GM. 2004. Avaliação dos Brejos de Altitude de Pernambuco e Paraíba, quanto à diversidade de briófitas, para a conservação. In: Pôrto KC, Cabral JJP, Tabarelli M. (eds.) Brejos de altitude em Pernambuco e Paraíba: história natural, ecologia e conservação. Brasília, Ministério do Meio Ambiente. p. 79-97.

Purvis W. 2000. Lichens. The Natural History Museum, Londom.

Rincón-Espitia AJR. 2011. Composición de la flora de líquenes corticícolas en el Caribe colombiano. Msc Thesis, Universidad Nacional de Colombia, Colombia.

Rivas Plata E, Lücking R, Aptroot A, et al. 2006. A first assessment of the Ticolichen biodiversity inventory in Costa Rica: the genus Coenogonium (Ostropales: Coenogoniaceae), with a world-wide key and checklist and a phenotype-based cladistic analysis. Fungal Diversity 23: 255-321.

Rodrigues LC. 2012. A comunidade de microliquens crostosos sofre alteração ao longo de gradientes ambientais na caatinga? Msc Thesis, Universidade Federal de Sergipe, Brazil.

Sipman HJ, Lücking R, Aptroot A, Chaves JL, Kalb K, Umaña LT. 2012. A first assessment of the Ticolichen biodiversity inventory in Costa Rica and adjacent areas: the thelotremoid Graphidaceae (Ascomycota: Ostropales). Phytotaxa 55: 1-214.

Sørensen T. 1948. A method of establishing groups of equal amplitude in plant sociology based on similarity of species and its application to analyses of the vegetation on Danish commons. Biologiske Skrifter 5: 1-34.

Spielmann AA. 2006. Cheklist of lichens and lichenicolous Fungi of Rio Grande do Sul (Brazil). Caderno de Pesquisa. Série Biologia (UNISC) 18: 7-125.

Tabarelli M, Santos AMM. 2004. Uma breve descrição sobre a história natural dos brejos nordestinos. In: Pôrto KC, Cabral JJP, Tabarelli M. (eds.) Brejos de altitude em Pernambuco e Paraíba: história natural, ecologia e conservação. Brasília, Ministério do Meio Ambiente. p. 17-24.

Umaña L \& Sipman H. 2002. Liquenes de Costa Rica/Costa Rica Lichens. Santo Domingo de Heredia, Instituto Nacional de Biodiversidad.

Villarouco FMO, Freire EVC, Pereira ECG, Pérez REU. 2007. Análise do líquen Cladonia verticillaris (Raddi) Fr., em condições de laboratório sob efeito do estireno e ciclohexano. Interciencia 32: 242-246.

Webster J, Weber R. 2007. Introduction to Fungi. 3rd. edn. New York, Cambridge University Press.

Xavier-Leite AB, Menezes AA, Aptroot A, Cáceres MES. 2014a. Coenogonium chlocoticum (Ascomycota: Coenogoniaceae), a new corticolous lichen species from Mata do Pau-Ferro, in Paraiba, NE Brazil. Nova Hedwigia 98: 197-200.

Xavier-Leite AB, Menezes AA, Andrade AO, Aptroot A, Cáceres MES. 2014b. Three new Stirtonia species (Arthoniales) from Reserva Muralha, NE Brazil, with a worldwide key to the species. Nova Hedwigia 98: 425-430. 